\title{
АСОЦАЦІЯ АЦЕТИЛЯТОРНОГО СТАТУСУ ШКОЛЯРІВ, ХВОРИХ НА БРОНХІАЛЬНУ АСТМУ ФІЗИЧНОГО НАПРУЖЕННЯ, ІЗ ЗРУШЕННЯМ ПОКАЗНИКІВ ІМУННОГО ЗАХИСТУ
}

Кафедра педіатрії та дитячих інфекційних хвороб (зав. - проф. О. К. Колоскова) ВНЗ

України «Буковинський державний медичний університет»<sunocher@ukr.net>

\begin{abstract}
Проведено комплексне обстеження 50 дітей шкільного віку, хворих на бронхіальну астму фізичного напруження (БАФН), яку діагностували за наявності в анамнезі хворого появи симптомів БА після фізичного навантаження та/або визначення індексу бронхоспазму більше 15 \% при проведенні спірографічної проби з дозованим бігом. За ащетиляторним фенотипом хворих розподілили на дві клінічні групи. «Швидкий» ащетиляторний фенотип у дітей, хворих на БАФН, асоиіюється з вірогідним ризиком виснаження киснезалежного метаболізму еозинофільних гранулоцитів крові за даними тесту з нітросинім тетразолієм (СШІ - 6,1 [95\% ДІ 3,3-11,3]) та зниженням фагоцитарного числа даних ефекторних клітин (СШ - 12,5 [95 \% ДІ 6,4-24,5]). Повільний тип ацетилювання у пацієнтів з фенотипом БАФН збільшує ризик реєстрації підвищеної конщентращії ІЛ-5 у сироватці крові порівняно з особами II групи, зокрема показник відносного ризику становить 2,8 (95\% ДІ 2,2-3,5) при співвідношенні шансів 6,2 (95\% ДI 3,2-12), що, імовірно, пов'язано з атопічним запальним процесом організму $i$ дозволяе персоналізувати лікувальну тактику.
\end{abstract}

Ключові слова: бронхіальна астма фізичної напруги; діти; фенотип; інтерлейкіни; імуноглобуліни.

Постановка проблеми й аналіз останніх досліджень. Нині алергічні захворювання є глобальною проблемою, з якою пов'язані значні медико-соціальні та економічні затрати в світі. Алергічні реакції реєструють у понад 50 \% населення Європи, з них більше 30 \% у дітей. При цьому бронхіальну астму (БА) відмічають у 5-10\% випадків. Серед 15 млн інвалідів у світі частка хворих на БА становить 1 \%, тобто це захворювання посідає 4-те місце у структурі причин інвалідизації дітей віком від 10 до 14 років [3].

Відомо, що БА належить до мультифакторних захворювань, етіологія та патогенез яких визначаються складною взаємодією генетичних чинників і факторів навколишнього середовища [2, 11]. Мультифакторність БА зумовлена, імовірно, різними фенотипами БА $[1,6]$, які вимагають використання персоналізованої терапії для досягнення контролю та оптимізації якості життя хворих на БА дітей.

За даними літератури, саме поліморфізм генів, які кодують ферменти другої фази детоксикації ксенобіотиків, впливає на функціональність даних ферментів та підвищує генетичну схильність до окислювального стресу і БА [5].

Дослідження патогенетичних особливостей БА фізичного напруження залежно від особливостей ацетиляторного фенотипу безсумнівно дозволить вирішити питання щодо індивідуалізованого вибору лікувальної тактики для досягнення контролю за БА у даних пацієнтів.

Ураховуючи зазначене вище, вважаємо за доцільне оцінити особливості імунної системи у дітей, хворих на БА фізичного напруження, залежно від особливостей ацетиляторного фенотипу, оскільки дані про них суперечливі та потребують подальшого вивчення.

Мета дослідження - для оптимізації комплексного лікування БА фізичного напруження вивчити деякі показники імунної системи у крові хворих шкільного віку з урахуванням їх ацетиляторних фенотипів.

Матеріали і методи. У пульмонологічному відділенні обласної дитячої клінічної лікарні Чернівців у період ремісії комплексно обстежено 50 дітей шкіль- 
ного віку, хворих на БА фізичного напруження (БАФН, «еxercise induced asthma»). БАФН діагностували за наявності в анамнезі хворого симптомів БА після фізичного навантаження та/або визначення індексу бронхоспазму більше 15 \% при проведенні спірографічної проби з дозованим бігом. За ацетиляторним фенотипом хворих розподілено на дві клінічні групи. До І клінічної групи ввійшло 27 пацієнтів, у яких визначали повільний тип ацетилювання (середній відсоток ацетильованого сульфадимезину в сечі становив менше 75 \%). II клінічну групу становили 23 школярі, у яких відмічали швидкий тип ацетилювання (середній відсоток ацетильованого сульфадимезину в сечі становив більше 75 \%) [7].

І клінічну групу становили 17 (62,9 \%) хлопчиків та 10 (37,1 \%) дівчаток. До II групи ввійшло 18 (78,3 \%; $\mathrm{P} \varphi>0,05)$ хлопчиків та 5 (21,7\%; $\mathrm{P} \varphi>0,05)$ дівчаток. Середній вік хворих I групи становив $(13,2 \pm 0,4)$ року, II групи $(11,3 \pm 0,6)$ року $(\mathrm{P}>0,05)$. До І клінічної групи ввійшло $63 \%$ міських та $37 \%$ сільських жителів, до II - 14 (60,9 \%) жителів міст і міських поселень та 9 (39,1 \%; $\mathrm{P} \varphi>0,05)$ хворих, які проживають у селах. Таким чином, за статтю, віком та місцем проживання клінічні групи порівняння достовірно не різнилися.

Як показники функціонального стану еозинофільних лейкоцитів крові визначали їх фагоцитарну активність (ФА, \%) методом Є. Н. Мосягіної. Також оцінювали киснезалежний метаболізм еозинофільних та нейтрофільних гранулоцитів (НГ) крові за показниками спонтанного і стимульованого НСТ-тесту у вигляді відносного вмісту цих фармазанпозитивних клітин. Вміст у сироватці крові імуноглобулінів (Ig) класів A, G, M визначали методом радіальної імунодифузії за G. Mancini та співавт., загального IgE, інтерлейкіну (ІЛ) - IЛ-4 та IЛ-8 у сироватці крові - методом імуноферментного аналізу з використанням стандартних наборів реагентів. Швидкість процесів ацетилювання досліджували методом Пребстинг - Гаврилова в модифікації О. М. Тимофеєвої, враховуючи, що ацетиляторний фенотип характеризував особливості II фази системи біотрансформації ксенобіотиків.

Статистичну обробку результатів дослідження здійснювали методами варіаційної статистики, використовуючи статистичну програму StatSoft Statistica v5.0., та з позиції клінічної епідеміології з урахуванням атрибутивного (АР), відносного (ВР) ризиків і співвідношення шансів (СШ) з визначенням 95 \% довірчого інтервалу (95\% ДІ).

Результати та іх обговорення. При аналізі показників киснезалежної метаболічної активності НГ крові, за даними НСТ-тесту, між групами порівняння не виявлено достовірної різниці за середніми показниками (табл. 1).

Таблиия 1. Показники НСТ-тесту нейтрофільних гранулоцитів крові дітей груп порівняння $(M \pm m)$

\begin{tabular}{l|c|c|c|c|c}
\hline \multirow{2}{*}{$\begin{array}{c}\text { Клінічна } \\
\text { група }\end{array}$} & \multirow{2}{*}{$n$} & \multicolumn{4}{|c}{ Показники НСТ-тесту } \\
\cline { 3 - 6 } & & $\begin{array}{c}\text { спонтанного } \\
\text { формазан-пози- } \\
\text { тивних клітин, \% }\end{array}$ & ЦХК, ум. од. & $\begin{array}{c}\text { формазан-пози- } \\
\text { тивних клітин, \% }\end{array}$ & ЦХК, ум. од. \\
\hline \hline I & 27 & $30,3 \pm 2,6$ & $0,37 \pm 0,17$ & $41,6 \pm 4,6$ & $0,55 \pm 0,12$ \\
II & 23 & $29,4 \pm 2,5$ & $0,33 \pm 0,15$ & $37,5 \pm 6,4$ & $0,45 \pm 0,18$ \\
P : I : II & & $>0,05$ & $>0,05$ & $>0,05$ & $>0,05$ \\
\hline
\end{tabular}

При оцінці маркерів киснезалежного метаболізму еозинофільних лейкоцитів крові між групами спостереження також не виявлено достовірної різниці (табл. 2).

Незважаючи на те, що статистично достовірної різниці за показниками киснезалежної метаболічної активності еозинофільних і нейтрофільних гранулоцитів крові між групами порівняння не відмічено, рівень спонтанного НСТ-тесту еозинофілів за даними ЦХК у дітей, хворих на БАФН, при повільному типі ацетилювання щодо пацієнтів 3 швидким ацетиляторним статусом був вищим практично 
у 1,5 раза. Отримані дані зумовлені, імовірно, підвищеною метаболічною виснаженістю головних прозапальних клітин алергічного запалення - еозинофілів при фенотипі «швидких ацетиляторів» у дітей, хворих на БАФН. Рівень спонтанного НСТ-тесту еозинофільних лейкоцитів крові за ЦХК менше 0,1 ум. од. спостерігали у $(68,4 \pm 10,6) \%$ дітей, хворих на БАФН з «швидким» ацетиляторним статусом, та лише у $(26,0 \pm 8,4) \%$ пацієнтів I клінічної групи $\left(\mathrm{P}_{\circ}<0,05\right)$. Отже, при швидкому ацетиляторному фенотипі у дітей, хворих на БАФН, підвищувався відносний ризик виснаження киснезалежного метаболізму еозинофілів периферичної крові у 2,4 раза [95 \% ДІ 1,7-3,4] при співвідношенні шансів 6,1 [95 \% ДI 3,3-11,3]. Наведені результати можна пояснити більш активним втягненням еозинофільних гранулоцитів у реалізацію запалення при БАФН у разі швидкого ацетиляторного фенотипу, що можна використати під час розробки адресного протизапального лікування хворих.

Таблиця 2. Показники НСТ-тесту еозинофільних гранулоцитів крові дітей груп порівняння $(M \pm m)$

\begin{tabular}{l|c|c|c|c|c}
\hline \multirow{2}{*}{$\begin{array}{c}\text { Клінічна } \\
\text { група }\end{array}$} & \multirow{2}{*}{$n$} & \multicolumn{4}{|c}{ Показники НСТ-тесту } \\
\cline { 3 - 6 } & & \multicolumn{2}{|c}{ спонтанного } & \multicolumn{2}{c}{ стимульованого } \\
\cline { 3 - 6 } & \multicolumn{2}{c|}{$\begin{array}{c}\text { формазан-пози- } \\
\text { тивних клітин, \% }\end{array}$} & ЦХК, ум. од. & $\begin{array}{c}\text { формазан-пози- } \\
\text { тивних клітин, \% }\end{array}$ & ЦХК, ум. од. \\
\hline \hline I & 27 & $14,6 \pm 2,1$ & $0,21 \pm 0,03$ & $15,3 \pm 2,3$ & $0,17 \pm 0,02$ \\
II & 19 & $15,3 \pm 1,7$ & $0,15 \pm 0,02$ & $16,6 \pm 1,7$ & $0,18 \pm 0,03$ \\
P : I : II & & $>0,05$ & $>0,05$ & $>0,05$ & $>0,05$ \\
\hline
\end{tabular}

Аналізуючи результати фагоцитарної активності (ФА) НГ крові, не встановили достовірної різниці у середніх показниках між групами порівняння. Так, у дітей I клінічної групи ФА НГ становила в середньому $(75,8 \pm 6,1) \%$, а у дітей II групи - $(80,3 \pm 4,5) \%(\mathrm{P}>0,05)$. Фагоцитарне число (ФЧ) цих гранулоцитів у групах порівняння становило $(8,7 \pm 0,8)$ ум. од. та $(9,7 \pm 0,9)$ ум. од. відповідно $(\mathrm{P}>0,05)$.

Разом з тим не виявлено також достовірної різниці між групами спостереження при проведенні порівняльного аналізу маркерів фагоцитарної активності еозинофільних гранулоцитів крові. Так, у хворих I групи середньогруповий показник ФА еозинофільних гранулоцитів крові становив $(64,2 \pm 2,8) \%$, а у пацієнтів II групи - $(67,5 \pm 3,2) \%(\mathrm{P}>0,05)$, рівень ФЧ даних клітин - $(3,2 \pm 0,6)$ ум. од. та $(1,8 \pm 0,9)$ ум. од. відповідно $(\mathrm{P}>0,05)$. Тобто у пацієнтів з «швидким» ацетиляторним статусом рівень ФЧ еозинофілів крові був майже вдвічі нижчим порівняно $з$ хворими з «повільним» ацетиляторним фенотипом. Рівень ФЧ еозинофільних лейкоцитів крові нижче 1,8 ум. од. відмічали у $(77,7 \pm 8,1) \%$ дітей 3 швидким типом ацетилювання та у $(21,7 \pm 8,6) \%$ хворих з повільним $\left(\mathrm{P}_{\varphi}<0,05\right)$. Показники ризику зниження ФЧ провідних ефекторних клітин алергічного запалення - еозинофілів крові нижче 1,8 ум. од. при швидкому типі ацетилювання були такими щодо «повільних ацетиляторів» у дітей з фенотипом БА фізичного напруження: відносний ризик - 3,5 [95 \% ДІ 2,4-5,2] при співвідношенні шансів 12,5 [95 \% ДІ 6,4-24,5]. Отримані результати підтверджують раніше припущення про превалювання еозинофільного характеру запалення при БАФН у разі «швидкого» типу ацетилювання, що дозволяє розробити індивідуалізований підхід до протизапального лікування дітей, хворих на БА, при відомому ацетиляторного статусі.

Порівняльний аналіз показників гуморальної ланки імунітету у периферичній крові дітей з фенотипом БАФН при різній активності $\mathrm{N}$-ацетилтранферази показав, що вміст ІЛ-8 в сироватці крові хворих обох клінічних груп суттєво не різнився, однак практично у 3-4 рази перевищував норму за даними виробника (2 пг/мл). Так, середній вміст ІЛ-8 у сироватці крові осіб, у яких реєстрували повільний тип ацетилювання, становив $(6,8 \pm 0,8)$ пг/мл та $(9,9 \pm 1,3)$ пг/мл 
$(\mathrm{P}>0,05)$ у пацієнтів другої клінічної групи. Водночас у половини $(55,5$ \%) дітей 3 «повільним ацетиляторним типом» відмічалося зниження вмісту ІЛ-8 у сиро-

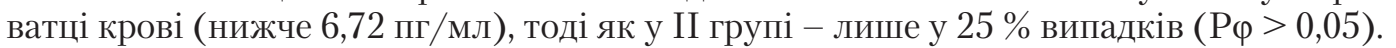
Показано, що повільний тип ацетилювання у дітей, хворих на БАФН, асоціювався із зниженням концентрації ІЛ-8 у сироватці крові (нижче 6,72 пг/мл) порівняно з групою дітей з «швидким ацетиляторним типом», зокрема відносний ризик - 1,8 [95\% ДІ 1,3-2,7], абсолютний ризик - 0,3 при СШ 3,7 [95\% ДІ 2,0-6,8].

Важливими індикаторами хронічного алергічного запалення при БА є сироватковий вміст IЛ-4 та IЛ-5, біологічний ефект яких пов'язаний з регуляцією синтезу IgE та підтримкою еозинофільного запалення в респіраторному тракті [8]. При порівняльному аналізі вмісту ІЛ-4 в сироватці крові школярів обох клінічних груп не виявлено достовірної різниці. Так, середня концентрація IЛ-4 у сироватці крові дітей I групи становила $(12,6 \pm 2,6)$ пг/мл, а в осіб II групи $(13,6 \pm 3,4)$ пг/мл $(\mathrm{P}>0,05)$.

Водночас у переважної більшості пацієнтів I групи (83,3 \%) зареєстровано підвищений вміст IЛ-5 (понад 3,7 пг/мл) у сироватці крові, тоді як у II - лише у $44,4 \%$ (Р $\varphi>0,05)$. Встановлено тенденцію до підвищення вмісту IЛ-5 у сироватці крові дітей, хворих на БАФН, при повільному характері ацетилювання, що відповідає даним літератури, згідно з якими вказується на чітку асоціацію між цим ацетиляторним фенотипом БА й атопічним запальним процесом організму [10]. Відмічено, що при повільному характері ацетилювання у пацієнтів з фенотипом БАФН збільшується ризик реєстрації підвищеної концентрації ІЛ-5 у сироватці крові порівняно з II групою, зокрема показник відносного ризику становив 2,8 [95 \% ДІ 2,2-3,5] при СШ 6,2 [95 \% ДІ 3,2-12].

Оскільки розвиток БА асоціюється з вродженим, генетично детермінованим гіперпродукуванням IgE [4], досліджено його вміст у сироватці крові обстежених дітей. Установлено, що вміст загального IgE у сироватці крові практично всіх хворих (90,6 \%) перевищував популяційну норму здорових дітей (120 МО/мл), однак у пацієнтів I клінічної групи він був дещо нижчим. Так, вміст загального $\operatorname{IgE~y~сироватці~крові~школярів~з~повільним~ацетиляторним~фенотипом~становив~}$ у середньому 631,5 МО/мл, а в осіб II клінічної групи - 862,8 МО/мл (P > 0,05). Водночас у понад половини (56,2 \%) дітей з «повільним ацетиляторним типом» відмічали нижчі за середньогрупові значення показники вмісту IgE у сироватці крові (менше $600 \mathrm{MO} /$ мл), тоді як у II групі - лише у $25 \%$ (Р $\varphi>0,05)$. При цьому повільний тип ацетилювання у дітей, хворих на БАФН, збільшував ризик вмісту загального IgE у сироватці крові менше 600 МО/мл із СШ 3,8 [95 \% ДI 2,1-7]. Особливість концентрації загального IgE в сироватці крові дітей, хворих на БАФН, при повільному ацетиляторному фенотипі зумовлена, імовірно, «виснаженням» організму за рахунок більш вираженого запального процесу в дихальних шляхах.

Згідно з даними літератури [9], вміст Ig класів M, G та А опосередковано вказує на активність запального процесу в організмі. Виходячи з цього, проведено аналіз концентрації цих імуноглобулінів у сироватці крові (табл. 3).

Таблиия 3. Показники концентрації імуноглобулінів основних класів у сироватці крові дітей, хворих на бронхіальну астму фізичного напруження, з різними ацетиляторними фенотипами $(M \pm m)$

\begin{tabular}{|c|c|c|c|}
\hline Показник & І група & II група & $\mathrm{P}$ \\
\hline IgM & $1,7 \pm 0,4$ & $1,4 \pm 0,3$ & $>0,05$ \\
\hline $\operatorname{IgG}$ & $12,8 \pm 1,3$ & $11,9 \pm 0,8$ & $>0,05$ \\
\hline Ig A & $1,5 \pm 0,3$ & $1,4 \pm 0,1$ & $>0,05$ \\
\hline
\end{tabular}

Незважаючи на те, що між групами порівняння не виявлено достовірної різниці за середнім рівнем IgM у сироватці крові, його значення нижче 1,6 мг/мл 
реєстрували практично у всіх обстежених (90,5 \%) II групи порівняно 3 83,6 \% осіб з повільним ацетиляторним фенотипом $(\mathrm{P} \varphi>0,05)$.

Разом з тим у половини пацієнтів I групи спостерігали підвищений вміст IgA у сироватці крові порівняно з дітьми з швидким ацетиляторним фенотипом. Так, концентрацію IgA в сироватці крові вище 1,5 мг/мл визначали у 52,9 \% школярів із середнім вмістом ацетиляторного сульфадимезину в сечі менше 75 \% та лише у $22,5 \%$ осіб $(\mathrm{P} \varphi<0,05)$ II клінічної групи.

Повільний тип ацетилювання у школярів, хворих на БАФН, асоціювався 3 підвищенням рівня IgA сироватки крові, що можна пояснити так: відносний ризик - 1,8 [95 \% ДІ 1,2-2,7] при СШ 3,8 [95 \% ДІ 2-7,1].

Таким чином, для фенотипу БАФН в дитячому віці залежно від характеру ацетиляторних процесів характерні певні відмінності у показниках ефекторної ланки імунітету, які проявляються у зниженні активності киснезалежного метаболізму еозинофільних гранулоцитів крові їх фагоцитарної здатності у дітей з швидким характером ацетилювання. Водночас у більшості пацієнтів з БАФН та «повільним» ацетиляторним фенотипом відмічається підвищений ризик збільшення концентрації IЛ-5, IЛ-8 та Ig класів M, G і А у сироватці крові, що опосередковано свідчить про вираженість запального процесу у даних осіб.

Висновки. 1. «Швидкий» ацетиляторний фенотип у дітей, хворих на БАФН, асоціюється з вірогідним ризиком виснаження киснезалежного метаболізму еозинофільних гранулоцитів крові за даними тесту з нітросинім тетразолієм (ВР 2,4 [95 \% ДІ 1,7-3,4], СШ - 6,1 [95 \% ДІ 3,3-11,3]) та зниженням ФЧ даних ефекторних клітин (ВР - 3,5 [95 \% ДІ 2,4-5,2], СШ - 12,5 [95 \% ДІ 6,4-24,5]). 2. Повільний характер ацетилювання у пацієнтів з БАФН асоціюється з ризиком підвищення вмісту в сироватці крові ІЛ-5 > 6,72 пг/мл із СШ 6,2 [95 \% ДІ 3,2-12]. 3. При повільному ацетиляторному фенотипі БАФН підвищується ризик реєстрації збільшеної концентрації IgA понад 1,5 мг/мл (СШ - 3,8), що пов'язано з вираженим запальним процесом в організмі та дозволяє персоналізувати лікувальну тактику у цих пацієнтів. 4. При розробці плану базисного протизапального лікування БАФН слід враховувати індивідуальний ацетиляторний тип дитини, що дозволить підвищити ефективність терапії та менеджменту захворювання.

$$
\text { С пи сок літ ератури }
$$

1. Безруков Л. О., Тарнавсъка С.І. Особливості перебігу неатопічного фенотипу бронхіальної астми в дітей залежно від характеру їх ацетиляторного статусу // Здоровье ребёнка. - 2014. - Вип. 53, № 2. C. $25-28$.

2. Брагіна Е. Ю., Фрё̈дін М. Б., Тен І. А. та ін. Поліморфізм ксенобіотиків метаболізму генів глутанін S-трансферази ( GSTT1, GSTM1) та цитохрому P450 (CYP2E1 i CYP2C19) в пацієнтів з атопічною бронхіальною астмою // Бюл. Сиб. відділення Poc. AMH. - 2005. - № 13. - С. 121-125.

3. Уманеи T. Р. Бронхиальная астма и аллергический ринит: пути оптимизации комплайенса и эффективности лечения // Астма та алергія. - 2015. - № 1. - С. 61-64.
1. Bezrukov L. O., Tarnavs'ka S. I. Osoblivosti perebigu neatopichnogo fenotipu bronhial'noï astmi v ditej zalezhno vid harakteru ïh acetilyatornogo statusu // Zdorov'e rebyonka. - 2014. - Vip. 53, № 2. - S. 25-28.

2. Bragina E. Yu., Freidin M. B., Ten I. A. ta in. Polimorfizm ksenobiotikiv metabolizmu geniv glutanin S-transferazi (GSTT1, GSTM1) ta citohromu P450 (CYP2E1 i CYP2C19) v pacientiv $\mathrm{z}$ atopichnoyu bronhial'noyu astmoyu // Byul. Sib. viddilennya Ros. AMN. - 2005. - № 13. - S. 121-125.

3. Umanec T. R. Bronhial'naya astma i allergicheskij rinit: puti optimizacii komplajensa i ehffektivnosti lecheniya // Astma ta alergiya. - 2015. - № 1. - S. 61-64.

4. BartaJ., Ghosh B. N-Acetyltransferases as markers for asthma and allergic // Atopic disorders current drug metabolism. - 2008. - Vol. 9, N 6. - P. 546-553.

5. BatraJ., Sharma S. K., Ghosh B. Arylamine N-acetyltransferase gene polymorphism: markers for atopic asthma, serum IgE and blood eosinophil counts // Molecular Biology. - 2009. - Vol. 43, N 1. - P. 55-67.

6. Cатро P., Rodríguez F., Sánchez-García S. at al. Phenotypes and endotypes of uncontrolled severe asthma: new treatments // J. Investig. Allergol. Clin. Immunol. - 2013. - Vol. 23, N 2. - P. 76-88. 
7. Eisner M. D., Yegin A., Trzaskoma B. Severity of Asthma Score Predicts Clinical Outcomes in Patients With Moderate to Severe Persistent Asthma // Chest. - 2012. - Vol. 141, N 1. P. 58-65.

8. Golden M. P., Henderson W. R. Leukotrienes // The New Engl. J. of Med. - 2009. - Vol. 357. P. $1841-1854$.

9. Kovalev I. E., Kovaleva V. L. Mechanisms of immunoglobulin action in bronchial asthma therapy // Pharmacentical chemistry J. - 2007. - Vol. 41, N 4. - P. 3-7.

10. Nacak M., Aynacioglu A. S., Filiz A. at al. Association between the N-acetylation genetic polymorphism and bronchial asthma // Br. J. Clin. Oharmacol. - 2002. - Vol. 54, N 6. - P. $671-$ 674.

11. Tatarskyy P. F., Chumachenko N. G., Kucherenko A. M. et al. Study on possible role of CYP1A1, GSTT1, GSTM1, GSTP1, NAT2 and ADRB2 genes polymorphisms in bronchial asthma development in children // Biopolymers and Cell. - 2011. - Vol. 27, N 1. - P. 66-73.

\section{АССОЦИАЦИЯ АЦЕТИЛЯТОРНОГО СТАТУСА БОЛЬНЫХ \\ БРОНХИАЛЬНОЙ АСТМОЙ ФИЗИЧЕСКОГО НАПРЯЖЕНИЯ ШКОЛЬНИКОВ СО СДВИГОМ В ПОКАЗАТЕЛЯХ ИММУННОЙ ЗАЩИТЫ}

\section{У. И. Марусик (Черновцы)}

Проведено комплексное обследование 50 детей школьного возраста, больных бронхиальной астмой физического напряжения (БАФН), которую диагностировали при наличии в анамнезе больного появлений симптомов БА после физической нагрузки и/или при определении индекса бронхоспазма более 15 \% во время спирографической пробы с дозированным бегом. По ацетиляторному фенотипу больных разделили на две клинические группы. «Быстрый» ацетиляторный фенотип у детей, больных БАФН, ассоциируется с вероятным риском истощения кислородозависимого метаболизма эозинофильных гранулоцитов крови по данным теста с нитросиним тетразолием (СШ - 6,1 [95 \% ДИ 3,3-11,3]) и снижением фагоцитарного числа этих эффекторных клеток (СШ - 12,5 [95 \% ДИ 6,4-24,5]). Медленный тип ацетилирования у пациентов с БАФН увеличивает риск регистрации повышенной концентрации ИЛ-5 в сыворотке крови по сравнению с лицами II группы, в частности показатель относительного риска составляет 2,8 [95 \% ДИ 2,2-3,5] при соотношении шансов 6,2 [95 \% ДИ 3,2-12], что, вероятно, связано с атопическим воспалительным процессом в организме и позволяет персонализировать лечебную тактику.

Ключевые слова: бронхиальная астма физического напряжения; дети; фенотип; интерлейкины; иммуноглобулины.

\section{ASSOCIATION ACETYLATION STATUS OF PATIENTS WITH ASTHMA PHYSICAL EXERTION SCHOOL-AGE CHILDREN WITH A SHIFT IN TERMS OF IMMUNE DEFENSE}

\section{U. I. Marusyk (Chernivtsi, Ukraine)}

Higher State Educational Establishment of Ukraine "Bukovinan State Medical University"

Conducted a comprehensive survey of 50 school-age children suffering from asthma physical exertion that was diagnosed by a history of the patient information on the appearance of asthma symptoms after physical activity and/or determine the index of bronchospasm more than $15 \%$ during spirographic samples from the dosed run. For acetylation phenotype patients were divided into two clinical groups. The presence of "fast" acetylation phenotype in children with asthma physical exertion, associated with probable risk of depletion oxygen-dependent metabolism eosinophilic granulocytes blood according to the test with nitroblue tetrazolium (OR - 6,1 [95 \% CI $3,3-11,3])$ and reduced the number of data phagocytic effector cells (OR - 12,5 [95 \% CI 6,4-24,5]). The slow type of acetylation phenotype in patients with asthma physical exertion increases the risk register high concentration of IL-5 in serum representatives regarding the second group, in particular, the rate of relative risk of 2,8 [95\% CI 2,2-3,5] at odds ratio 6,2 [95\% CI 3,2-12], which is probably associated with atopic inflammation of the body and allows personalized treatment policy in these patients.

Key words: asthma physical exertion; children phenotypes; interleukins; immunoglobulins. 